\title{
Urinary Calcium Excretion After Immobilization and Spinal Fusion in Adolescents
}

\author{
F. J. C. MILLARD, J. R. NASSIM, and J. W. WOOLLEN \\ From The Royal National Orthopaedic Hospital and St. George's Hospitul, Londoin
}

\begin{abstract}
Millard, F. J. C., Nassim, J. R., and Woollen, J. W. (1970). Archives of Disease in Childhood, 45, 399. Urinary calcium excretion after immobilization and spinal fusion in adolescents. The effect of prolonged immobilization and spinal fusion on the urinary calcium excretion of adolescents is described. Some patients developed severe hypercalcuria, but there was considerable individual variation. No significant difference was found between the sexes nor between patients with scoliosis due to muscle weakness and idiopathic scoliosis.
\end{abstract}

An increase in urinary calcium excretion following immobilization has been found by several workers (Howard, Parson, and Bingham, 1945; Deitrich, Whedon, and Shorr, 1948; Whedon and Shorr, 1957; Issekutz et al., 1966; and Rose, 1966); the majority of the patients in these studies were adult. This paper describes the effect of immobilization and spinal fusion on a group of adolescents. Spinal fusion is an extensive operation involving the removal of parts of approximately 12 vertebrae and the insertion of bone chips taken from the iliac crest. The operation is usually preceded by three to four weeks' immobilization and followed by six months' immobilization. The object of this study was to see how high the urinary calcium excretion would rise under these circumstances, for how long this would remain high, and whether there was any difference between the sexes. In addition, we wondered whether there was any difference between those with scoliosis due to muscular weakness and those with idiopathic scoliosis.

\section{Patients and Methods}

Twelve patients ( 5 boys and 7 girls) were studied. At the time of admission when the first specimens were collected their ages ranged from 12 to 16 years. All the patients were suffering from severe progressive scoliosis. In 3 patients the scoliosis was thought to be due to muscle weakness following an attack of poliomyelitis; though severely incapacitated, these patients were all able to bear weight. 8 patients were diagnosed as having idiopathic adolescent scoliosis (Manning,

Received 17 October 1969.
1967). One (R.H.) who had had scoliosis since birth also had arachnodactyly, but no other manifestations of Marfan's syndrome. Posterior spinal fusion was performed according to the method of Harrington (1962).

All the patients had been treated previously in a Milwaukee brace (Blount, Schmidt, and Bidwell, 1958). After admission to hospital each patient was immobilized in a plaster of Paris cast (Risser, 1955). Posterior spinal fusion was carried out 3 to 8 weeks after immobilization. In one patient fusion was performed in two stages. After fusion the patients remained in a plaster cast for 6 months. While immobilized they were able to move their arms and legs but did not bear weight. 2 patients had surgical treatment for deformities of their legs during the period of immobilization following fusion.

Twenty-four hour specimens of urine were collected before immobilization and at intervals for 5 to 7 months during immobilization. Urinary calcium was measured according to the method of MacIntyre (1961). In some cases the initial 24-hour specimen was collected two days after admission. The calcium content may have been affected by the change from home to ward diet. No attempt was made to control the patient's diet while in the ward.

Blood for calcium and urea was taken during the 24-hour period of urine collection.

\section{Results}

The results are shown in Table I and Fig. 1 and 2. The 24-hour urinary calcium rose after immobilization and spinal fusion, but there was considerable individual variation. Thus L.F. (Fig. 2) showed a rapid rise reaching over $400 \mathrm{mg} . / 24$ hours; in contrast, M.Y. (Fig. 2) showed a comparatively slight increase to $192 \mathrm{mg}$./24 hours. No difference 
TABLE I

24-Hour Urinary Calcium (mg.) for Each Patient before Immobilization, Highest Figure after Immobilization, and Increase

\begin{tabular}{|c|c|c|c|c|c|}
\hline Patient & Sex & Diagnosis & $\begin{array}{c}\text { Before } \\
\text { Immobilization }\end{array}$ & $\begin{array}{l}\text { Highest After } \\
\text { Immobilization }\end{array}$ & Increase \\
\hline $\begin{array}{l}\text { M.B. } \\
\text { R.C. } \\
\text { G.G. } \\
\text { R.H. } \\
\text { M.H. } \\
\text { P.D. } \\
\text { L.F. } \\
\text { V.N. } \\
\text { S.T. } \\
\text { M.Y. } \\
\text { L.W. } \\
\text { S.S. }\end{array}$ & $\begin{array}{l}M \\
M \\
M \\
M \\
M \\
F \\
F \\
F \\
F \\
F \\
F \\
F\end{array}$ & $\begin{array}{l}\text { Paralytic } \\
\text { Paralytic } \\
\text { Paralytic } \\
\text { Scoliosis with arachnodactyly } \\
\text { Idiopathic } \\
\text { Idiopathic } \\
\text { Idiopathic } \\
\text { Idiopathic } \\
\text { Idiopathic } \\
\text { Idiopathic } \\
\text { Idiopathic } \\
\text { Idiopathic }\end{array}$ & $\begin{array}{r}121 \\
154 \\
59 \\
143 \\
76 \\
150 \\
91 \\
113 \\
156 \\
71 \\
115 \\
64\end{array}$ & $\begin{array}{l}304 \\
195 \\
380 \\
185 \\
195 \\
288 \\
433 \\
398 \\
465 \\
192 \\
282 \\
194\end{array}$ & $\begin{array}{r}183 \\
41 \\
321 \\
42 \\
119 \\
138 \\
342 \\
285 \\
309 \\
121 \\
167 \\
130\end{array}$ \\
\hline
\end{tabular}

was found between the boys and the girls either in the initial level of 24-hour urinary calcium or in the increase after immobilization and fusion, neither was there any difference in response when the children with paralytic and idiopathic scoliosis were compared (See Table II).

In all patients the urinary calcium reached a peak 1 to 12 weeks after the start of immobilization and subsequently fell. In 6 patients it did not fall to control levels, but the difference between the level before immobilization and the level during the fifth and sixth months of immobilization was small. The greatest difference was recorded in L.F. (Fig. 2), who also had the highest urinary calcium. Her 24-hour urinary calcium before immobilization was $91 \mathrm{mg}$. and after 6 to 7 months' immobilization varied between $160 \mathrm{mg}$. and $209 \mathrm{mg}$. $/ 24$ hours. In both the patients who had operations on their legs during the period of immobilization after fusion, the urinary calcium rose after the operation.

The serum calcium and blood urea, which were estimated during the 24-hour period of urine collection, were within normal limits. The rise in urinary calcium was not associated with a rise in $\underset{\mathscr{E}}{\omega}$ serum calcium.

\section{Discussion}

The results show that the increase in urinary calcium excretion after immobilization and spinal fusion is no greater than that recorded by other workers. For example, Rose (1966), who studied a group of patients most of whom were immobilized either with prolapsed discs or leg fractures, found that the urinary calcium frequently rose to over $400 \mathrm{mg}$. $/ 24$ hours. In our patients balance studies were not attempted, so it is impossible to be certain of the over-all calcium loss. However, it is likely $\overrightarrow{\vec{O}}$ that those with a high urinary calcium excretion were in strongly negative calcium balance. Deitrich et al. (1948), Whedon and Shorr (1957), and Rose (1966) found a conspicuous negative calcium balance in immobilized patients. Rose, who studied 4 ก young men, found a mean negative balance of $\overline{7}$ $530 \mathrm{mg}$. $/ 24$ hours; over a period of 3 months this would amount to a loss of about $50 \mathrm{~g}$. calcium. These 4 patients were selected because they showed

TABLE II

Means for Each Group with Standard Deviation and Range

\begin{tabular}{|c|c|c|c|}
\hline Group & Before Immobilization & Highest After Immobilization & Increase \\
\hline $\begin{array}{l}\text { Boys (5) } \\
\text { Girls (7) } \\
\text { Paralytic (3) } \\
\text { Idiopathic (8) }\end{array}$ & $\begin{array}{c}111 \pm 41 \\
\text { (Range: } 76-154) \\
109 \pm 36 \\
\text { (Range: } 71-156) \\
111 \pm 48 \\
\text { (Range: } 59-154 \text { ) } \\
\quad 104 \pm 35 \\
\text { (Range: } 64-156 \text { ) }\end{array}$ & $\begin{array}{c}252 \pm 87 \\
\text { (Range: 185-380) } \\
322 \pm 111 \\
\text { (Range: 192-465) } \\
293 \pm 93 \\
\text { (Range: } 195-380 \text { ) } \\
306 \pm 112 \\
\text { (Range: } 192-465 \text { ) }\end{array}$ & $\begin{array}{c}141 \pm 116 \\
\text { (Range: } 41-321 \text { ) } \\
213 \pm 95 \\
\text { (Range: } 121-342) \\
182 \pm 140 \\
\text { (Range: } 41-321 \text { ) } \\
\quad 201 \pm 94 \\
\text { (Range: } 119-342 \text { ) }\end{array}$ \\
\hline
\end{tabular}

No significant difference was found between the boys and girls or between the paralytic and idiopathic groups. 

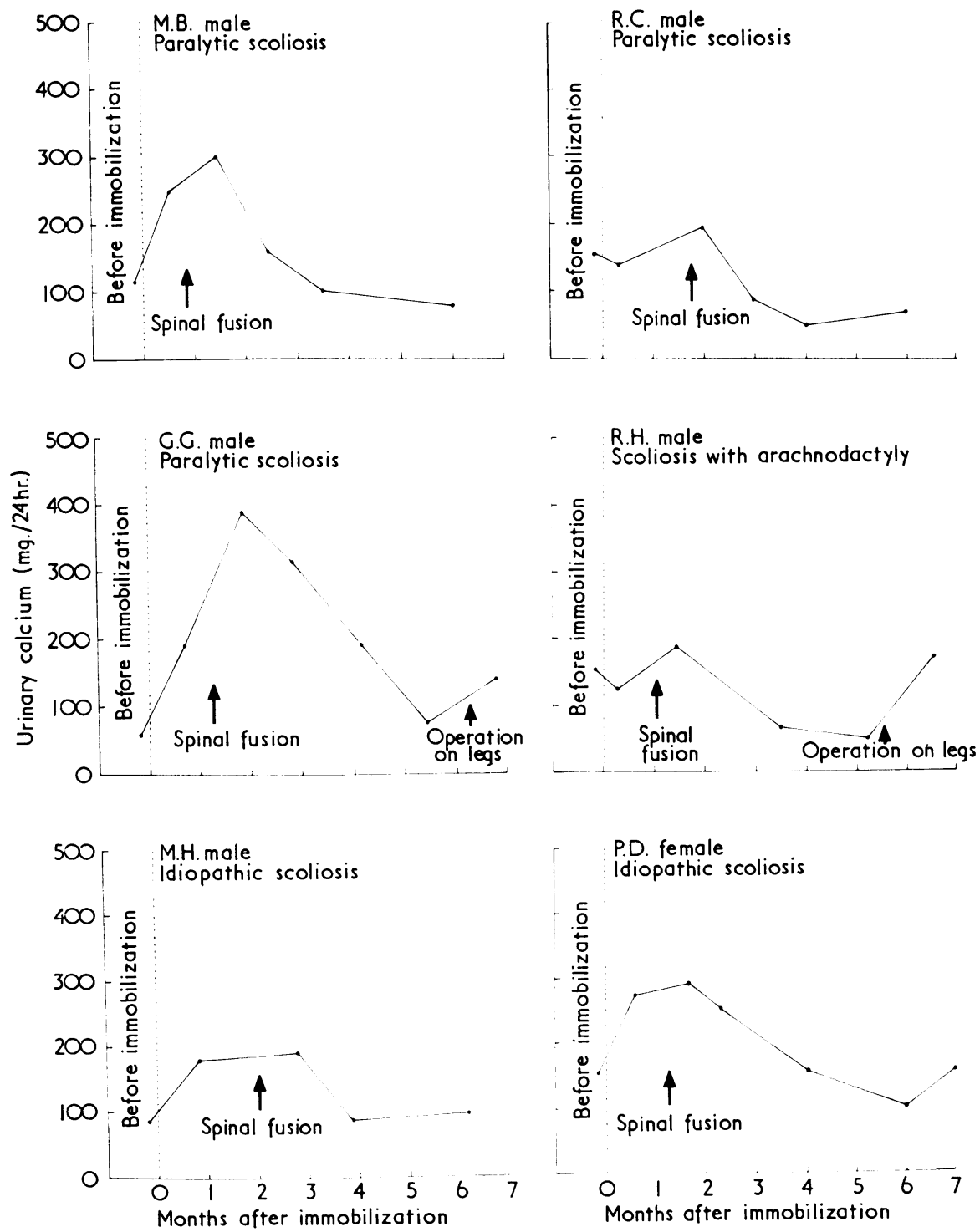

FIG. 1.-24-hour urinary calcium (mg.) before and after immobilization.

severe hypercalciuria. In our patients there was considerable individual variation in the increase in urinary calcium, and the mean negative balance is likely to have been less. However, our patients were immobilized for as long as 7 to 8 months and, though in all cases the urinary excretion started to fall after 3 to 4 months, those with persistently high urinary calcium levels probably lost a comparable amount of calcium. In an adolescent, $50 \mathrm{~g}$. calcium would amount to $5-10 \%$ of the total body calcium.

It is often assumed that calcium lost during immobilization is replaced when the patient is mobilized, but, as Rose points out, there is no conclusive evidence for this. Deitrich et al. (1948) showed a slight positive calcium balance in 4 healthy young men during mobilization; the subjects were in positive balance before immobilization, and there 

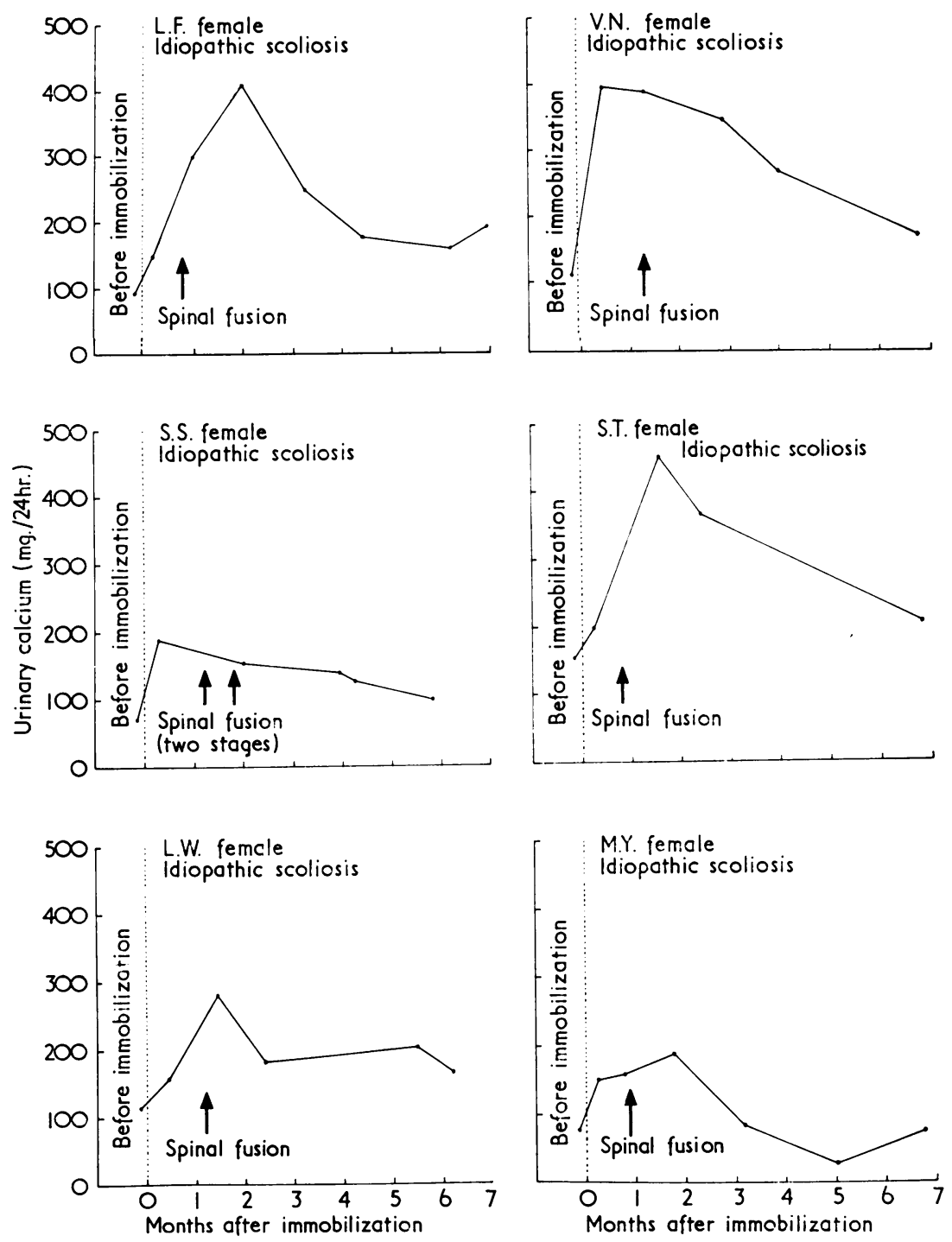

FIG. 2.-24-hour urinary calcium before and after immobilization.

was no significant difference in the calcium balance before and after the period of immobilization. Issekutz et al. (1966) found that in normal young men the urinary calcium excretion almost always fell to levels less than those before immobilization, suggesting a period of positive calcium balance, but balance studies were not done.

It would be of great interest to study the calcium balance of children after a long period of immobili- zation in order to see whether the calcium lost was replaced. However, this would require further time in hospital and would probably be an unjustified interference with a child's life. It might be possible to reduce calcium loss during immobilization by giving a thiazide diuretic, such as bendrofluazide, which has been shown to reduce urinary calcium levels in patients with idiopathic hypercalciuria (Higgins et al., 1964). In this condition 
thiazides can reduce negative calcium balance or convert a negative balance to a positive one (Yendt, Gagné, and Cohanim, 1966; Harrison and Rose, 1968). Bendrofluazide may have a similar action in immobilized patients, and further studies are required to see the effect of this form of treatment.

Estimations of urinary calcium excretion were not done frequently enough to separate the effect of spinal fusion from that of immobilization. The two patients who had operations on their legs after fusion both showed a subsequent rise in urinary calcium; this may have been a direct effect of the operation or have been due to the increased immobilization in bed after it.

Rose (1966) found that the rise in urinary calcium during immobilization was most severe in young men. Our results showed that the girls tended to have a greater increase than the boys, but the numbers were small and the difference between the sexes was not significant. Neither was there any difference between the patients with scoliosis due to muscle weakness and those with idiopathic scoliosis.

We wish to thank Mr. C. W. S. F. Manning for permission to study his patients, Dr. P. G. Walker and his staff for the biochemical investigations, Miss A. Hilb and the Sister and staff of the Metabolic Ward who supervised the collection of specimens, and Dr. P. Zorab for helpful advice and criticism.
REFERENCES

Blount, W. P., Schmidt, A. C., and Bidwell, R. G. (1958). Making the Milwaukee brace. Fournal of Bone and foint Surgery, 40A, 526.

Deitrich, J. E., Whedon, G. D., and Shorr, E. (1948). Effects of immobilisation upon various metabolic and physiologic functions of normal men. American fournal of Medicine, 4, 3.

Harrington, P. R. (1962). Treatment of scoliosis. Fournal of Bone and foint Surgery, 44A, 591.

Harrison, A. R., and Rose, G. A. (1968). The effect of bendrofluazide on urinary and faecal calcium and phosphorus. Clinical Science, 34, 343.

Higgins, B. A., Nassim, J. R., Collins, J., and Hilb, A. (1964). The effect of bendrofluazide on urine calcium excretion. Clinical Science, 27, 457.

Howard, J. E., Parson, W., and Bingham, R. S., Jr. (1945). Studies on patients convalescent from fracture. III. The urinary excretion of calcium and phosphorus. Bulletin of the fohns Hopkins Hospital, 77, 291.

Issekutz, B., Jr., Blizzard, J. J., Birkhead, N. C., and Rodahl, K. (1966). Effect of prolonged bed rest on urinary calcium output. Fournal of Applied Physiology, 21, 1013.

MacIntyre, I. (1961). Flame photometry. Advances in Clinical Chemistry, 4, 1.

Manning, C. W. S. F. (1967). The spine-excluding lumbo-sacral spine. In Clinical Surgery, Ed. by G. C. Lloyd-Roberts. Vol. 13, Orthopaedics. p. 358 . Ed. by C. Rob and R. Smith. Butterworths, London.

Risser, J. C. (1955). Scoliosis. The application of body casts for the correction of scoliosis. Instructional Course Lectures, American Academy of Orthopedic Surgeons, 12, 255.

Rose, G. A. (1966). Immobilisation osteoporosis. British fournal of Surgery, 53, 769.

Whedon, G. D., and Shorr, E. (1957). Metabolic studies in paralytic acute anterior poliomyelitis. II. Alterations in calcium and phosphorus metabolism. Fournal of Clinical Investigation, 36, 966.

Yendt, E. R., Gagné, R. J. A., and Cohanim, M. (1966). The effects of thiazides in idiopathic hypercalciuria. American Fournal of Medical Sciences, 251, 449. 